\title{
Analisis Sikap Ilmiah Calon Guru PAI dalam Perspektif Gender
}

\author{
Adi Fadli \\ Universitas Islam Negeri Mataram, Nusa Tenggara Barat, Indonesia \\ email: adi.fadli@uinmataram.ac.id
}

\begin{tabular}{|c|c|c|}
\hline \multicolumn{3}{|c|}{$\begin{array}{l}\text { The purpose of this study was to analyze the ability of the scientific attitude of PAI } \\
\text { teacher candidates from a gender perspective. A total of } 148 \text { prospective teachers of } \\
\text { Islamic Religious Education (PAI) as a sample in the study conducted consisted of } 67 \\
\text { men and } 81 \text { women. The sampling technique uses a cluster random sampling } \\
\text { technique with a cross-sectional survey research design. Research data were analyzed } \\
\text { using t-test different test. Research data collection uses a scientific attitude } \\
\text { questionnaire instrument and interview guidelines to obtain data on the scientific } \\
\text { attitude of PAI teacher candidates based on gender. The results showed that the } \\
\text { scientific attitude of PAI FITK prospective teachers of Mataram State University did } \\
\text { not have a significant difference from a gender perspective. }\end{array}$} \\
\hline \multicolumn{3}{|c|}{ I teacher candidates, } \\
\hline $\begin{array}{c}\text { First Receive: } \\
15 \text { October } 2019\end{array}$ & $\begin{array}{c}\text { Revised: } \\
2 \text { November } 2019\end{array}$ & $\begin{array}{r}\text { Ac } \\
15 \mathrm{Nov}\end{array}$ \\
\hline $\begin{array}{c}\text { Final Proof Recieved: } \\
\text { 10 December } 2019 \\
\end{array}$ & \multicolumn{2}{|c|}{$\begin{array}{c}\text { Published: } \\
21 \text { December } 2019\end{array}$} \\
\hline \multicolumn{3}{|c|}{$\begin{array}{l}\text { How to cite (in APA style): } \\
\text { Fadli, A. (2019). Analisis Sikap Ilmiah Calon Guru PAI dalam Perspektif Gender. } \\
\text { Schemata, } 8 \text { (2), 51-58. }\end{array}$} \\
\hline
\end{tabular}

\section{PENDAHULUAN}

Learning outcome pada Perguruan Tinggi (KKNI Level 6) menuntut tercapainya tujuan pembelajaran yang mencakup 3 aspek yaitu sikap, pengetahuan, serta keterampilan umum dan khusus sehingga aspek sikap ilmiah menjadi indikator utama tercapainya tujan pembelajaran di level Perguruan Tinggi. Pengembangan sikap ilmiah mahasiswa sangat urgen untuk dilakukan untuk mewujudkan perspektif yang lebih berimbang dalam menghadapi konflik, permasalahan sosial, serta untuk dapat bersaing dalam menghadapi era globalisasi ${ }^{149}$. Hasil penelitian terdahulu juga menunjukkan bahwa pengembangan sikap ilmiah berpengaruh positif terhadap peningkatan kemampuan mahasiswa dalam memahami konsep, bahkan mampu meningkatkan kualitas pemikiran ${ }^{150}$. Akan tetapi, berbagai hasil penelitian terdahulu membuktikan bahwa pengembangan sikap ilmiah, pembentukan

149 Lawson, A. E, "Formal Reasoning, Achievement, and Intelligence: An Issue of Importance." Science Education 66 (1), 1982: 77-83.

150 Olasahinde, J.K., \& Olatoye, A.R, "Scientific Attitude, Attitude to Science and Science Achievement of Senior Secondary School Students in Katsina State, Nigeria." Journal of Educational and Social Research 4(1), 2014. 
karakter $^{151}$ dan pengembangan keterampilan sosial dalam pembelajaran cenderung terabaikan, khususnya dalam praktek pembelajaran pada Islamic Studies ${ }^{152}$.

Pengembangan sikap ilmiah di perguruan tinggi mutlak harus dilakukan, terlebih lagi untuk calon guru Pendidikan Agama Islam (PAI) sehingga akan melahirkan generasi muda yang tidak hanya cerdas secara intelektual semata, tetapi juga cerdas secara emosional, sosial, moral, dan spritual. Akan tetapi, berdasarkan studi empiris di Indonesia menunjukkan bahwa aspek sikap ilmiah hanya menjadi dampak pengiring dalam proses dan tercapainya tujuan pembelajaran, di mana proses pembelajaran lebih terfokus pada penguasaan aspek kognitif baik pada bidang ilmu sains ${ }^{153,154155}$, maupun dalam jurusan bidang ilmu studi islam ${ }^{156,157}$. Berdasarkan studi empiris tersebut mengungkap bahwa permasalahan tersebut disebabkan karena praktek pembelajaran yang bersifat teacher centered dan minimnya penerapan meode ilmiah dalam proses pembelajaran. Dengan demikian, kondisi tersebut menjadi permasalahan yang sangat urgen untuk segera dicarikan alternatif solusi sehingga dapat berpengaruh terhadap pengembangan sikap ilmiah mahasiswa di Perguruan Tinggi, khususnya di jurusan Islamic studies.

Sikap ilmiah mengacu pada sifat dan perilaku yang diharapkan pada individu yaitu kejujuran, kesadaran, toleransi, tanggung jawab, dan berpikir kritis ${ }^{158}$. Selain itu, sikap bukanlah perilaku akan tetapi kecenderungan dalam bertindak dan cara merespon obyek tertentu dan berkaitan dengan proses mental ${ }^{159}$, bahkan sikap merupakan ekspresi yang muncul dari kebutuhan manusia dan mencerminkan proses intelektual seseorang ${ }^{160}$ (Wheeler, Goodale \& Deese, 1974). Indikator sikap ilmiah terdiri dari rasionalitas,

151 Ibrahim, A.A., Hassan, S.S.S., \& Hashim, S "The Effect of Instructional Video Drama on Students' Perceptions on The Observance of Islamic Ethics: An Experimental Approach.“ International Journal of Education and Research 4(10), 2016: 49-62.

152 Al-Attas, S. N. Aims and Objectives of Islamic Education, London: Hodder and Stoughton. 1979.

153 Mukhtar, M "Meningkatkan Motivasi Belajar Mahasiswa Melalui Pembelajaran Model Problem Solving Materi Stoikiometri." Lantanida Jurnal 5(2), 2017: 93-196.

154 Ismiani, S., Syukri., \& Wahyudiati, D "Pengaruh Penerapan Metode Problem Based Learning Terhadap Sikap Ilmiah dan Hasil Belajar Biologi Siswa Kelas VII MTS NW 01 Kembang Kerang." Biota 10(1), 2017: 68-75.

155 Wahyudiati, D “Analisis Efektivitas Kegiatan Praktikum Sebagai Upaya Peningkatan Hasil Belajar Mahaisswa." Jurnal Tastqif 14(2), 2016: 143-168.

156 Asrori, A "Islamic Education Development Strategy in Facing the Global Challenges." International Journal of Science and Research (IJSR) 11 (4), 2015: 587-592.

157 Lonto., Apeles, L "Pengembangan Model Pendidikan Karakter Berbasis Nilai Sosio-Kultural Pada Siswa SMA di Minahasa.” Mimbar, 31(2), 2015: 319-327.

${ }^{158}$ Hamilton, R. L., \& Swortzel, K. A “Assessing mississippi aest teachers' capacity for teaching science integrated process skills." Journal of Southern Agricultural Education Research 57(1), 2007: 1-22.

159 Eagly, A. H., \& Chaiken, S. Attitude structure and function. In D. T. Gilbert, S. T. Fiske, \& G. Lindzey (Eds.), The handbook of social psychology (pp. 269-322). New York, NY, US: McGraw-Hill. 1998.

${ }^{160}$ Wheeler, L., Goodale, R., \& Deese, J. General psychology. Oxford, UK: Allyn \& Bacon. 1974.

\section{Copyright $\odot 2019$ Schemata Journal}

Available online at http://journal.uinmataram.ac.id/index.php/schemata 


\section{Adi Fadli, Analisis Sikap Ilmiah Calon Guru PAI dalam Perspektif Gender}

keingintahuan, keterbukaan pikiran, sikap jujur, objektivitas, toleransi, menghormati pandangan orang lain, kreatif dan penemuan, bekerjasama dengan orang lain, berpikir kritis, dan sikap peduli terhadap lingkungan ${ }^{161}$. Komponen-komponen sikap ilmiah tersebut mutlak harus dikembangkan dari tingkat pendidikan dasar sampai pada tingkat Perguruan Tinggi sehingga tujuan pembelajaran dapat tercapai dengan optimal sehingga sangat penting untuk dilakukan penelitian untuk mengukur kemampuan sikap ilmiah calon guru PAI sebagai acuan dalam merancang, melaksanakan, dan mengevaluasi praktek pembelajaran di level Perguruan Tinggi.

Kemampuan sikap ilmiah calon guru tidak hanya dipengaruhi oleh penerapan pendekatan dan metode pembelajaran yang diterapkan pada kegiatan pembelajaran, akan tetapi terdapat hubungan yang positif antara peningkatan sikap ilmiah dengan hasil belajar mahasiswa ditinjau dari aspek gender. Berbagai kajian literatur sebelumnya telah membuktikan terdapat perbedaan sikap ilmiah berdasarkan gender ${ }^{162,163}$. Menariknya, terdapat temuan yang berbeda yang menunjukkan tidak terdapat perbedaan sikap ilmiah berdasarkan gender ${ }^{164}$. Dengan demikian, sangat urgen dilakukan penelitian untuk memetakan kondisi terkini sikap ilmiah calon guru PAI FITK Universitas Islam Negeri Mataram yang sampai saat ini belum pernah dilakukan sehingga hasil penellitian ini diharapkan dapat mengeksplorasi kemampuan sikap ilmiah calon guru PAI ditinjau dari perspektif gender.

\section{LANDASAN TEORI}

Definisi sikap yaitu kecenderungan psikologis belajar yang teridentifikasi secara positif atau negatif, menunjukkan perasaan emosional, serta menunjukkan tingkat kebaikan atau ketidaksenangan terhadap sesuatu seperti konsep, orang ataupun suatu kondisi ${ }^{165}$. Adapun secara psikologis, sikap merupakan kondisi internal seseorang yang dapat

161 Harlen, W "Purposes and Procedures for Assessing Science Process Skills. "Assessment in Education 6(1), 1999: 129-144.

162 Hacieminoglu., E "Elementary School Students' Attitude Toward Science and Attitude Toward Science and Related Variables." International Journal of Environmental \& Science Education 11(2), 2015: 35-52.

163 Zeidan, H.A., \& Jayosi, R. M "Science Process Skills and Attitudes Toward Science Among Palestinian Secondary School Students." World Journal of Education 1(5), 2014: 13-24.

164 Dhindsa, H. S. \& Chung, G "Attitudes and Achievement of Bruneian Science Students." Internalational Journal of Science Education 25, 2003: 907-922.

165 Oskamp, S., \& Schultz, P. W “Attitudes and Opinions (3rd Ed.). Mahwah, NJ: Lawrence Erlbaum Associates. 2005.

\section{Copyright $\odot 2019$ Schemata Journal}

Available online at http://journal.uinmataram.ac.id/index.php/schemata 


\section{Adi Fadli, Analisis Sikap Imiah Calon Guru PAI dalam Perspektif Gender}

disimpulkan melalui pengamatan, respon, ataupun tanggapan yang diberikan ${ }^{166}$. Lebih lanjut sikap didefinisikan sebagai ekspresi yang muncul dari kebutuhan individu yang mencerminkan proses intelektual seseorang ${ }^{167}$ sehingga sikap ilmiah merupakan aspek yang sangat urgen untuk dikembangkan dalam proses pembelajaran untuk melahirkan individu atau lulusan yang siap menghadapi tantangan global dan bersaing di dunia kerja.

Berbagai hasil penelitian terdahulu telah mengungkap adanya hubungan antara sikap ilmiah dengan gender dan grade levels yang memiliki korelasi positif dengan hasil belajar mahasiswa. Fakta menarik membuktikan bahwa jenis kelamin merupakan faktor yang paling signifikan dalam mempengaruhi sikap ilmiah ${ }^{168}$, di mana siswa laki-laki memiliki kemampuan sikap ilmiah yang cenderung lebih positif daripada siswa perempuan. Temuan hasil penelitian berbeda menunjukkan bahwa tidak terdapat perbedaan sikap ilmiah berdasarkan gender ${ }^{169}$. Selain faktor gender, terdapat faktor lain yang mempengaruhi sikap ilmiah mahasiswa yaitu lingkungan belajar dan penerapan pendekatan dan model pembelajaran. Hal ini berarti bahwa proses pembelajaran yang bersifat teacher centered dan monoton mengakibatkan munculnya sikap negatif mahasiswa terhadap prosedur-prosedur metode ilmiah, khususnya pada mahasiswa di bidang islamic studies. Kondisi tersebut sangat relevan dengan hasil penelitian yang telah dilakukan oleh Ajidagba yang melakukan penelitian terhadap siswa pada bidang studi islam yang menunjukkan bahwa sikap positif maupun negatif yang ditunjukkan dalam proses pembelajaran mempengaruhi prestasi belajar mahasiswa ${ }^{170}$. Lebih lanjut, Schibeci dan Riley mengemukakan bahwa sikap mempengaruhi prestasi, daripada prestasi mempengaruhi sikap. Siswa dengan sikap positif cenderung memiliki skor yang lebih tinggi pada pengukuran prestasi ${ }^{171}$.

${ }^{166}$ Krosnick, J. A., Judd, C. M., \& Wittenbrink, B. The Measurement of Attitudes. In D. Albarracín, B. T. Johnson, \& M. P. Zanna (Eds.), The handbook of attitudes (pp. 21-76). Mahwah, NJ, US: Lawrence Erlbaum Associates Publishers. 2005.

167 Wheeler, L., Goodale, R., \& Deese, J. General psychology. Oxford, UK: Allyn \& Bacon. 1974.

168 Jones G., Howe A., \& Rua M "Gender Differences in Students' Experiences, Interests, and Attitudes Towards Science and Scientists.” Sci. Educ., 84, 2000: 180-192.

169 Dhindsa, H. S. \& Chung, G "Attitudes and Achievement of Bruneian Science Students." Internalational Journal of Science Education 25, 2003: 907-922. Nigeria. 1990

170 Ajidagba, U. A. An overview of Islamic Education system in Nigeria. University of Ilorin,

${ }^{171}$ Weinburgh, M "Gender Differences in Student Attitudes Toward Science: A Metaanalysis 18. of The Literature from 1970 To 1991.” Journal of Research in Science Teaching 32, 1995: 387-398.

\section{Copyright $\odot 2019$ Schemata Journal}

Available online at http://journal.uinmataram.ac.id/index.php/schemata 


\section{METODE PENELITIAN}

Design penelitian menggunakan Cross-sectional survey design yaitu untuk mendeskripsikan situasi obyek penelitian yang memiliki dua variabel atau lebih ${ }^{172}$. Pengambilan sampel penelitian menggunakan teknik cluster random sampling dengan sampel penelitian sebanyak 148 orang calon guru PAI FITK dari Universitas Islam Negeri Mataram (67 orang laki-laki dan 81 orang perempuan).

Instrumen sikap ilmiah yang dalam penelitian ini menggunakan angket sikap ilmiah mahsiswa yang mengacu pada indikator sikap ilmiah yang telah dikembangkan oleh Harlen ${ }^{173}$, Gegga, dan AAAS/Association for Advancement of Science sehingga tersintesis 8 indikator sikap ilmiah dikembangkan menjadi 50 pernyataan. Adapun Indikator sikap ilmiah yang digunakan terdiri dari 8 indikator antara lain; rasa ingin tahu, refleksi kritis, keterbukaan pikiran, tekun, kerjasama, tanggung jawab, saling menghargai, dan peka terhadap lingkungan. Analisis data hasil penelitian dianalisis dengan uji beda t-test yang bertujuan untuk mengetahui apakah terdapat perbedaan sikap ilmiah calon guru PAI ditinjau dari perspektif gender.

\section{HASIL DAN PEMBAHASAN}

Data yang diperolah dari hasil penelitian berupa data kuantitatif berdasarkan hasil analisis angket untuk mengukur kemampuan sikap ilmiah mahasiswa calon guru PAI yang dianalisis dengan uji beda t-test. Selanjutnya untuk mengukur tingkat sikap ilmiah calon guru PAI berdasarkan gender dengan mengacu pada nilai mean (nilai rata-rata) yang diperoleh seperti ditunjukkan pada Tabel 1. Temuan hasil penelitian menunjukkan fakta menarik yaitu sikap ilmiah calon guru PAI yang perempuan sedikit lebih tinggi dibandingkan dengan calon guru PAI laki-laki, meskipun perbedaan tersebut tidak signifikan berdasarkan hasil uji t-test. Hasil uji t-test menunjukkan nilai $\mathrm{p}>0.05$ yang mengindikasikan tidak terdapat perbedaan sikap ilmiah calon guru PAI berdasarkan gender.

172 Creswell, J. W. Research design: Qualitative, quantitative, and mixed methods approaches. Thousand Oaks, CA: Sage. 2009.

173 Harlen, W "Purposes and Procedures for Assessing Science Process Skills." Assessment In Education 6(1), 1999: 129-144.

\section{Copyright $\odot 2019$ Schemata Journal}

Available online at http://journal.uinmataram.ac.id/index.php/schemata 
Adi Fadli, Analisis Sikap Ilmiah Calon Guru PAI dalam Perspektif Gender

Tabel 1 Statistik deskriptif sikap ilmiah mahasiswa berdasarkan Gender

\begin{tabular}{llll}
\hline Gender & N & Mean & SD \\
\hline Laki-laki & 67 & 196.15 & 15.79 \\
Perempuan & 81 & 198.04 & 14.71 \\
Total & 148 & & \\
\hline
\end{tabular}

Merujuk pada tujuan penelitian yang pertama adalah untuk mengetahui tingkat sikap ilmiah calon guru PAI FITK Universitas Islam Negeri Mataram berdasarkan gender, di mana temuan penelitian menunjukkan secara umum sikap ilmiah mahasiswa perempuan cenderung lebih tinggi dibandingkan dengan sikap ilmiah mahasiswa laki-laki. Temuan penelitian ini didukung oleh hasil penelitian terdahulu yang membuktikan bahwa faktor gender memiliki pengaruh terhadap sikap ilmiah ${ }^{174}$. Berbagai penelitian sebelumnya juga mengungkap fakta menarik yaitu perempuan memiliki sikap ilmiah yang lebih positif dibandingkan dengan laki-laki ${ }^{175,176}$. Adanya kecenderungan sikap ilmiah yang dimiliki perempuan lebih tinggi dari sikap ilmiah yang dimiliki laki-laki disebabkan karena perempuan memiliki komitmen dan tanggung jawab yang lebih tinggi di dalam menyelesaikan tugas perkuliahan dan menyelesaikan persoalan secara ilmiah. Selain itu, ditemukan fakta yang menunjukkan bahwa perempuan memiliki motivasi dan kecenderungan sikap yang lebih positif dibandingkan dengan laki-laki177.

Temuan hasil penelitian selanjutnya berkaitan dengan sikap ilmiah yang khas dimiliki oleh calon guru PAI yang ditinjau dari 8 indikator sikap ilmiah yang terdiri dari; rasa ingin tahu, refleksi kritis, keterbukaan pikiran, tekun, kerjasama, tanggung jawab, saling menghargai, dan peka terhadap lingkungan seperti yang ditunjukkan pada Tabel 2. Hasil penelitian mengungkap fakta menarik, di mana sikap tanggung jawab dan keterbukaan pikiran menempati posisi tertinggi, sedangkan sikap refleksi kritis menempati posisi terendah.

174 Zeidan, H.A., \& Jayosi, R. M "Science Process Skills and Attitudes Toward Science Among Palestinian Secondary School Students." World Journal of Education, 1(5), 2014: 13-24.

${ }^{175}$ Smist, J., M. General chemistry and self-efficacy.Massachusetts,ERIC Document ReproductionService, No. ED368558. 1993.

176 Villafane, S. M., \& Lewis, J. E "Exploring a Measure Of Science Attitude for Different Groups of Students Enrolled in Introductory College Chemistry." Chemistry Education Research and Practice 4(17), 2016: 731-742.

177 Dhindsa, H. S. \& Chung, G "Attitudes and Achievement of Bruneian Science Students. "Internalational Journal of Science Educatio, 25, 2003: 907-922.

\section{Copyright $\odot 2019$ Schemata Journal}

Available online at http://journal.uinmataram.ac.id/index.php/schemata 
Adi Fadli, Analisis Sikap Ilmiah Calon Guru PAI dalam Perspektif Gender

Tabel 2 Sebaran Soal untuk Setiap Indikator

\begin{tabular}{ll}
\hline Indikator & No of Item \\
\hline Rasa Ingin Tahu & $1-6$ \\
Refleksi Kritis & $7-12$ \\
Keterbukaan Pikiran & $13-17$ \\
Tekun & $18-25$ \\
Kerjasama & $26-31$ \\
Tanggung Jawab & $32-39$ \\
Saling Menghargai & $40-45$ \\
Peka Terhadap Lingkungan & $46-50$ \\
Overall & \\
\hline
\end{tabular}

Hasil angket tersebut sangat relevan hasil wawancara yang telah dilakukan dan diperoleh beberapa temuan penting antara lain; (1) rendahnya sikap refleksi kritis disebabkan oleh proses pembelajaran yang bersifat monoton dan didominasi oleh metode ceramah, (2) penerapan sistem perkuliahan masih bersifat teacher centered dan penerapan metode ilmiah dalam pembelajaran sangat jarang dilakukan. Kondisi tersebut berdampak pada rendahnya kemampuan sikap ilmiah dan pemhaman konsep mahasiswa. Temuan tersebut didukung oleh penelitian sebelumnya yang mengungkap bahwa lingkungan belajar sangat mempengaruhi sikap ilmiah yang dimiliki peserta didik ${ }^{178}$. Dengan demikian, lingkungan belajar yang kondusif dan bersifat student centered harus dirancang sehingga dapat mengembangkan sikap ilmiah mahasiswa ${ }^{179}$.

Berdasarkan hasil uji beda t-test diperoleh nilai $\mathrm{p}>0.05$ yaitu 0.457 yang berarti bahwa tidak terdapat perbedaan sikap ilmiah calon guru PAI berdasarkan gender. Temuan ini memiliki relevansi dengan hasil penelitian terdahulu yang membuktikan bahwa sikap ilmiah tidak dipengaruhi oleh gender ${ }^{180}$, artinya kemampuan sikap ilmiah yang dimiliki oleh laki-laki dan perempuan tidak memiliki perbedaan. Selain itu, sikap ilmiah dapat dipengaruhi oleh sejumlah faktor seperti sikap pendidik terhadap konsep, dan metodologi pembelajaran yang diterapkan oleh pendidik dalam proses pembelajaran ${ }^{181}$. Tidak

178 Aldridge, J. M., \& Fraser, B. J" A Cross-Cultural Study of Classroom Learning Environments in Australia and Taiwan." Learning Environments Research, 3, 2000: 101-134.

${ }^{179}$ Hacieminoglu., E "Elementary School Students' Attitude Toward Science and Attitude Toward Science and Related Variables." International Journal of Environmental \& Science Education 11(2), 2015: 35-52.

180 Dhindsa, H. S. \& Chung, G "Attitudes and Achievement of Bruneian Science Students. "Internalational Journal of Science Education, 25, 2003: 907-922.

181 Ajidagba, U. A. An overview of Islamic Education system in Nigeria. University of Ilorin, Nigeria.1 990. 


\section{Adi Fadli, Analisis Sikap Ilmiah Calon Guru P AI dalam Perspektif Gender}

terdapatnya perbedaan sikap ilmiah tersebut disebabkan oleh penerapan pendekatan dan model pembelajaran cenderung bersifat monoton, kurangnya pengaktifan siswa dalam menyelesaikan permasalahan melalui metode ilmiah Dengan demikian, melalui penerapan pembelajaran berbasis kolaboratif menjadi salah satu alternatif untuk dapat meningkatkan kemampuan berpikir kritis, sikap ilmiah, dan keterampilan pemecahan masalah mahasiswa ${ }^{182}$. Untuk dapat mengembangkan sikap ilmiah mahasiswa di level Perguruan Tinggi sangat dibutuhkan penelitian lanjutan dalam mengukur kemampuan sikap ilmiah yang lebih komprehensif dari tingkat primer, sekunder, maupun tersier. Terlebih lagi adanya keterbatasan kajian pada jurusan Islamic studies karena selama ini cenderng terpusat di bidang Sains.

\section{KESIMPULAN}

Berdasarkan temuan penelitian diperoleh kesimpulan sebagai berikut: 1) Tidak terdapat perbedaan sikap ilmiah calon guru PAI ditinjau dari perspektif gender; dan 2) Sikap ilmiah yang dimiliki calon guru PAI berdasarkan gender ditemukan lebih positif pada aspek tanggung jawab dan keterbukaan pikiran, tetapi memiliki respon negatif pada aspek refleksi kritis. Disarankan kepada dosen dan pihak terkait untuk mengembangkan sikap positif melalui penciptaan lingkungan belajar yang berorientasi pemecahan masalah dan berbasis kolaboratif sehingga dapat mengembangkan sikap ilmiah mahasiswa. Pengembangan sikap ilmiah mahasiswa dalam proses pembelajaran akan berdampak positif terhadap tercapainya tujuan pembelajaran yang mencakup aspek sikap, pengetahuan, dan keterampilan.

\section{DAFTAR PUSTAKA}

Adegboyega, L. O. (2016). Relationship between emotional intelligence and attitude towards examination of undergraduates at University of Ilorin. Unpublished seminar paper, Department of Counsellor Education, University of Ilorin, Ilorin, Nigeria.

Al-Attas, S. N. (1979), Aims and Objectives of Islamic Education, London: Hodder and Stoughton.

Aldridge, J. M., \& Fraser, B. J. (2000). A cross-cultural study of classroom learning environments in Australia and Taiwan. Learning Environments Research, 3, 101-134.

182 Irwanto, Rohaeti, E., \& Prodjosantoso, A. K “Undergraduate Students' Science Process Skills in Terms of Some Variables: A Perspective From Indonesia." Journal of Baltic Science Education 17(5), 2018: 751-772. 
Ajidagba, U. A. (1990). An overview of Islamic Education system in Nigeria. University of Ilorin, Nigeria.

Asrori, A. (2015). Islamic education development strategy in facing the global challenges. International Journal of Science and Research (IJSR), 11 (4), 587-592.

Creswell, J. W. (2009). Research design: Qualitative, quantitative, and mixed methods approaches. Thousand Oaks, CA: Sage.

Dhindsa, H. S. \& Chung, G. (2003). Attitudes and Achievement of Bruneian Science Students." Internalational Journal of Science Education 25, 907-922.

Eagly, A. H., \& Chaiken, S. (1998). Attitude structure and function. In D. T. Gilbert, S. T. Fiske, \& G. Lindzey (Eds.), The handbook of social psychology (pp. 269-322). New York, NY, US: McGraw-Hill.

Hacieminoglu., E.(2015). Elementary school students' attitude toward science and attitude toward science and related variables. International Journal of Environmental \& Science Education, 11(2), 35-52.

Hamilton, R. L., \& Swortzel, K. A. (2007). Assessing mississippi aest teachers' capacity for teaching science integrated process skills. Journal of Southern Agricultural Education Research, 57(1), 1-22. Retrieved from http://www.jsaer.org/.

Harlen, W. (1999). Purposes and procedures for assessing science process skills. Assessment in Education, 6(1), 129-144.

Ibrahim, A.A., Hassan, S.S.S., \& Hashim, S. (2016). The effect of instructional video drama on students' perceptions on the observance of Islamic ethics: An experimental approach. International Journal of Education and Research, 4(10), 49-62.

Irwanto, Rohaeti, E., \& Prodjosantoso, A. K. (2018b). Undergraduate students' science process skills in terms of some variables: A perspective from Indonesia. Journal of Baltic Science Education, 17(5), 751-772.

Ismiani, S., Syukri., \& Wahyudiati, D. (2017). Pengaruh penerapan metode problem based learning terhadap sikap ilmiah dan hasil belajar biologi siswa kelas vii mts nw 01 kembang kerang. Biota, 10(1), 68-75.

Jones G., Howe A., \& Rua M., (2000), Gender differences in students' experiences, interests, and attitudes towards science and scientists. Sci. Educ., 84, 180-192

Krosnick, J. A., Judd, C. M., \& Wittenbrink, B. (2005). The Measurement of Attitudes. In D. Albarracín, B. T. Johnson, \& M. P. Zanna (Eds.), The handbook of attitudes (pp. 21-76). Mahwah, NJ, US: Lawrence Erlbaum Associates Publishers.

Lawson, A. E. (1982). Formal reasoning, achievement, and intelligence: An issue of importance. Science Education, 66 (1), 77-83.

Lonto., Apeles, L. (2015). Pengembangan model pendidikan karakter berbasis nilai sosiokultural pada siswa sma di minahasa. Mimbar, 31(2), 319-327.

Mukhtar, M. (2017). Meningkatkan motivasi belajar mahasiswa melalui pembelajaran model problem solving materi stoikiometri. Lantanida Jumal, 5(2), 93-196.

Olasahinde, J.K., \& Olatoye, A.R. (2014). Scientific attitude, attitude to science and science achievement of senior secondary school students in katsina state, nigeria. Journal of Educational and Social Research, 4(1). 
Adi Fadli, Analisis Sikap Ilmiah Calon Guru PAI dalam Perspektif Gender

Oskamp, S., \& Schultz, P. W. (2005). Attitudes and opinions (3rd ed.). Mahwah, NJ: Lawrence Erlbaum Associates.

Smist, J., M. (1993). General chemistry and self-efficacy.Massachusetts, ERIC Document Reproduction Service, No. ED368558.

Villafane, S. M., \& Lewis, J. E. (2016). Exploring a measure of science attitude for different groups of students enrolled in introductory college chemistry. Chemistry Education Research and Practice 4(17), 731-742.

Wahyudiati, D. (2016). Analisis efektivitas kegiatan praktikum sebagai upaya peningkatan hasil belajar mahaisswa. Jurnal Tastgif, 14(2), 143-168.

Weinburgh, M. (1995). Gender differences in student attitudes toward science: a metaanalysis 18. of the literature from 1970 to 1991, Journal of Research in Science Teaching, 32, 387-398.

Wheeler, L., Goodale, R., \& Deese, J. (1974). General psychology. Oxford, UK: Allyn \& Bacon.

Zeidan, H.A., \& Jayosi, R. M. (2014). Science process skills and attitudes toward science among palestinian secondary school students. World Journal of Education, 1(5), 1324. 